\title{
Development, bromatological analysis and sensory evaluation of diet dulce de leche made with goat and bovine milks using xylitol as a sucrose replacement
}

\author{
Desenvolvimento, análise bromatológica e avaliação sensorial de doces de leite do tipo diet bovino e \\ caprino utilizando o xilitol como substituinte da sacarose
}

Desarrollo, análisis químico y evaluación sensorial de dulces de leche dietética de bovinos y caprinos utilizando xilitol como sustituto de la sacarosa

Received: 11/19/2021 | Reviewed: 11/27/2021 | Accept: 11/30/2021| Published: 12/11/2021

\author{
Laura Beatriz da Silva \\ ORCID: https://orcid.org/0000-0002-8094-6781 \\ Universidade Católica Dom Bosco, Brasil \\ E-mail: laura.bya.silva@gmail.com \\ Déborah Aparecida Bulde de Oliveira \\ ORCID: https://orcid.org/0000-0002-9030-1522 \\ Universidade Católica Dom Bosco, Brasil \\ E-mail: deborah.bulde@gmail.com \\ Ana Carolina Sebastião Serra \\ ORCID: https://orcid.org/0000-0001-5408-501X \\ Universidade Católica Dom Bosco, Brasil \\ E-mail: anacarolinasebastiaoserra@gmail.com \\ João Pedro Grespan Estodutto da Silva \\ ORCID: https://orcid.org/0000-0002-2312-4757 \\ Universidade Federal da Grande Dourados, Brasil \\ E-mail: jpestodutto@gmail.com \\ Lilliam May Grespan Estodutto da Silva \\ ORCID: https://orcid.org/0000-0001-7264-2617 \\ Universidade Católica Dom Bosco, Brasil \\ E-mail: 1maygrespan@gmail.com
}

\begin{abstract}
Dulce de leche is a product very appreciated by its consumers, for being a food rich in nutrients and with high energy value. On the other hand, many people have restrictions to consume it, due to its high glycemic index. Aiming to develop viable formulations of diet dulce de leche, using xylitol as a sucrose replacement with goat milk bovine milk. Four pasty dulce in leche formulations were developed: bovine milk with sucrose (F1), bovine milk with xylitol (F2), goat milk with sucrose (F3) and goat milk with xylitol (F4). Bromatological analysis was performed to determine the macronutrients and the Acceptance Test was used for the sensory analysis with application of the 9-point hedonic scale. In the bromatological analysis, the samples F1 and F3 had the highest carbohydrate contents, with $79.40 \%$ and $78.87 \%$ respectively, while the samples F2 and F4 had a carbohydrate content of $12.24 \%$ and $12.25 \%$, respectively. This difference had a direct impact on the determination of the Total Caloric Value (TCV) of the samples, since F1 and F3 formulations were the most caloric. As for the sensory analysis, all formulations were considered well accepted, as they presented an acceptability index above $70 \%$. The use of xylitol as a substitute proved to be viable. The dulce de leche with this sweetener in its composition were less caloric and the formulations were well accepted by the tasters. Therefore, it is possible to enable the use of this sweetener in the food industry.
\end{abstract}

Keywords: Acceptability; Sweetener; Total caloric value.

\section{Resumo}

O doce de leite é um produto muito apreciado pelos consumidores, por ser um alimento rico em nutrientes e de alto valor energético. Em contrapartida, inúmeras pessoas possuem restrições em consumi-lo, devido seu elevado índice glicêmico quando ingerido isoladamente. Este trabalho teve como objetivo desenvolver formulações viáveis de doce de leite diet, com a utilização do xilitol em substituição à sacarose em dois tipos de leite: caprino e bovino. Foram desenvolvidas quatro formulações de doce de leite pastoso: bovino com sacarose (F1), bovino com xilitol (F2), caprino com sacarose (F3) e caprino com xilitol (F4). Foi realizada análise bromatológica para determinação dos macronutrientes, e análise sensorial por meio da utilização do Teste de Aceitação, com aplicação da Escala Hêdonica de nove pontos. Na análise bromatológica, as amostras F1 e F3 apresentaram os maiores teores de carboidratos, com $79,40 \%$ e 78,87\%, respectivamente, enquanto que as amostras F2 e F4 apresentaram um teor de carboidratos de 12,24\% e $12,25 \%$, respectivamente. Esta diferença teve impacto direto na determinação do Valor Calórico Total (VCT) das 
amostras, o que já era esperado, uma vez que as formulações F1 e F3 foram as mais calóricas. Quanto à análise sensorial, todas as formulações foram consideradas bem aceitas, por terem apresentado um índice de aceitabilidade acima de $70 \%$. A utilização do xilitol como substituinte se mostrou viável. Os doces com este edulcorante em sua composição se apresentaram menos calóricos e as formulações foram bem aceitas pelos provadores. Portanto, pode-se pensar na propagação do uso deste edulcorante na indústria de alimentos.

Palavras-chave: Aceitabilidade; Edulcorante; Valor calórico total.

\section{Resumen}

Dulce de leche es un producto muy apreciado por los consumidores, ya que es un alimento rico en nutrientes y de alto valor energético. Por otro lado, numerosas personas tienen restricciones para consumirlo, debido a su alto índice glucémico cuando se ingiere solo. Este estudio tuvo como objetivo desarrollar formulaciones viables de leche dulce de dieta, con el uso de xilitol en lugar de sacarosa en dos tipos de leche: cabra y terneros. Se desarrollaron cuatro formulaciones de leche pastosa dulce: bovino con sacarosa (F1), bovino con xilitol (F2), caprino con sacarosa (F3) y caprino con xilitol (F4). Se realizó análisis bromatológico para determinar macronutrientes, y análisis sensorial mediante el Test de Aceptación, con aplicación de la Escala Hidónica de Nueve Puntos. En el análisis bromatológico, las muestras F1 y F3 presentaron los mayores contenidos de carbohidratos, con 79,40\% y 78,87\%, respectivamente mientras que las muestras F2 y F4 presentaron un contenido de carbohidratos de 12,24\% y 12,25\%, respectivamente. Esta diferencia tuvo un impacto directo en la determinación del Valor Calórico Total (TVC) de las muestras, lo que ya era esperado, ya que las formulaciones F1 y F3 fueron las más calóricas. En cuanto al análisis sensorial, todas las formulaciones se consideraron bien aceptadas porque presentaban un índice de aceptabilidad superior al $70 \%$. El uso de xilitol como sustituto demostró ser factible. Los dulces con este edulcorante en su composición eran menos calóricos y las formulaciones eran bien aceptadas por los catadores. Por lo tanto, uno puede pensar en la propagación del uso de este edulcorante en la industria alimentaria.

Palabras clave: Aceptabilidad; Edulcorante; Poder calórico total.

\section{Introduction}

Sweet milk is a product much appreciated by consumers, because it is a food rich in nutrients and high energy value. Its composition is based on the use of milk (commonly used bovine milk), common sugar, and sometimes baking soda, to correct acidity during preparation. All these ingredients are cooked for a certain time, until you get a sweet of creamy texture, brownish, bright coloration, and characteristic flavor (Silva et al, 2020).

The brownish color of the dulce de leche is due to the Maillard reaction, which causes browning in foods, due to the discoloration caused by the reaction between the carbonyl and the free amine groups, with subsequent formation of the melanoidin pigment. Also, when the $\mathrm{pH}$ of the candy is located in the range between 6.0 and 7.0 , this chemical reaction is benefited. The Maillard reaction is also responsible for the palatability and characteristic odor of the product in question. Another reaction involved in the process is the caramelization reaction, where the oxidation of sugar occurs, which also promotes different flavor and coloring to the food (Albuquerque et al, 2011; Silva et al, 2020).

However, despite being much appreciated, many people have restrictions to consume it, due to its high power of sweetness and high glycemic index, since this implies negatively in a certain pathology that the individual may have, such as obesity and diabetes. Research indicates that excess added sugar in the diet from industrialized foods is closely linked to the development of obesity, a risk factor for the emergence of cardiovascular diseases and metabolic diseases such as diabetes mellitus type 2 (Gaino \& Silva, 2011).

With the increasing prevalence of obesity and metabolic disorders, there is also an increase in the number of people who need to decrease and even cease sugar consumption. Xylitol, a polyalcohol whose molecular formula is $\mathrm{C}_{5} \mathrm{H}_{12} \mathrm{O}_{5}(1,2,3,4,5-$ pentadroxypentane), is a sweetener that can be used as a substitute for sucrose, because in addition to having similar sweetener power, its caloric value is only $2.4 \mathrm{kcal} / \mathrm{g}$. Another advantage of xylitol when compared to sucrose is its high microbiological stability, because even at low concentrations, it acts as a preservative of food products, and thus contributes with a longer shelf life. It can also be consumed by individuals with type 1 or type 2 diabetes mellitus, because unlike conventional sugars, it does not depend on the action of insulin to enter cells (Mussato \& Roberto, 2002). 
Another advantage of xylitol is its anticariogenic property. Caries results from an infectious process resulting from fermentation produced by bacteria, especially those of the genus Streptococcus found in the oral flora. Under acidic conditions, these microorganisms produce large amounts of lactic acid and synthesize extracellular polysaccharides that increase plaque adhesion in teeth. The anticariogenic of xylitol is mainly determined by its non-fermentability by bacteria of the genus Streptococcus, which decreases its proliferation in the oral flora (Mussato \& Roberto, 2002).

In relation to the milks used, when compared to bovine milk, goat milk has a higher digestibility, because it does not have agglutinin, an enzyme responsible for the union of fat globules. These, in turn, have reduced sizes, which causes the increase of the contact area, facilitates enzymatic action, and finally promotes better digestion (Zambom, 2005). In addition, one of its main characteristics is hypo allergenicity, which is due to the difference in the structural size of proteins, and have a low $\alpha s_{1}$ casein content (Cenachi, 2012). About 50\% of the human population is allergic to bovine milk, but is tolerant to goat milk (Park, Ramos \& Haenlein, 2007).

Taking into account the aspects mentioned, the objective of this work was to develop viable formulations of sweet diet milk, with the use of xylitol in place of sucrose in two types of milk: goat and cattle. For this, four types of sweets were produced: bovine milk with sucrose (F1), bovine milk with xylitol (F2), goat milk with sucrose (F3) and goat milk with xylitol (F4).

For the quantification of micros and macronutrients between formulations, preparation of nutritional table and comparison of caloric profiles, bromatological analyses were performed. Finally, a sensory analysis was performed to verify the acceptability of the public through the sweets produced.

\section{Material and Method}

\subsection{Material}

This work has an experimental design. Bovine milk was purchased on a farm located in the municipality of Ribas do Rio Pardo - MS, while goat milk was purchased on a farm in the district of Rochedinho - MS. Xylitol, sucrose and baking soda were acquired in the local trade of Campo Grande - MS.

\subsection{Preparation of milk sweet formulations}

Four different types of pasty milk sweet were produced: F1, F2, F3 and F4. The production of sweets, as well as bromatological and sensory analyses, were carried out in the laboratory of Food Technology of the Catholic University of Don Bosco Catholic (UCDB), in the city of Campo Grande - MS.

For the preparation of sweets, the milk acidity was initially corrected to $13^{\circ} \mathrm{D}$. Starting from the initial acidity of $18^{\circ} \mathrm{D}$, $46,70 \mathrm{~g}$ of baking soda was used for every 100 liters of milk, to obtain the desirable acidity of $13^{\circ} \mathrm{D}$.

In a pot, $1 \mathrm{~L}$ of milk was added and the pasteurization process was performed, heating $62^{\circ}$ to $65^{\circ} \mathrm{C}$, for 30 minutes. Then, $25 \%(250 \mathrm{~g})$ of sugar previously diluted in milk was added. The mixture was stirred constantly, while reducing, until the desired pasty concentration was reached. The final point of the milk candy was determined by adding a drop of the sweet in a glass with cold water, when it reached the bottom of the glass without breaking down, the process was finished. Soon after, the fire was turned off, and soon after, the product was bottled still hot in dry glass containers, properly sanitized, and these were turned upside down so that the lids were also treated by heat.

For the production of bovine milk sweets using xylitol, the same procedure described above was followed, in which xylitol was replaced only by sucrose. This same procedure was valid for the production of the other formulations, that is, sweet goat's milk with sucrose, and sweet goat milk with xylitol, in which substitutions were made only of the main components of the formulation, cow's milk by goat's milk, and sucrose by xylitol. 


\subsection{Bromatological analysis}

The moisture of the milk candy was determined by the drying method, a gravimetric procedure where water loss occurs by desiccation in an oven at $105^{\circ} \mathrm{C}$ until constant weight (AOAC, 2000). The determination of ash was made from a also gravimetric method, where the total destruction of the organic matter present in the sample occurs (AOAC, 2000).

For protein quantification, the amount of nitrogen was determined by the Micro-Kjeldahl method - neutralization titulometry, and the results were converted to crude protein, with application of the conversion factor for milk and dairy products (6.38) (AOAC, 2000). Lipids were determined through the Soxhlet extraction methodology, where the extraction of oils and fat is based on three stages: solvent extraction, solvent evaporation and weighing (AOAC, 2000).

To determine the carbohydrate content, the Lane-Eynon method was used, using the Fehling reagent (AOAC, 2000). All determinations were made in triplicates and then the means of the values were made. The results obtained were presented in percentage form and in tables.

\subsection{Determination of the total caloric value}

The total caloric value (TVC) was estimated, the conversion factors of Atwater and Woods (1896), of $4 \mathrm{kcal} \mathrm{g}^{-1}$ for proteins and carbohydrates and $9 \mathrm{kcal} \mathrm{g}^{-1}$ for lipids were considered. The results were expressed in kcal per $100 \mathrm{~g}$ of sample.

\subsection{Sensory analysis}

Sensory analyses were performed by tasting against variations of pasty milk candies produced, through the use of the preference and acceptance test, with application of the Nine-point Hydonic scale (Dutcosky, 2008), as shown in Annex 1.

Thirty untrained UCDB volunteers, of both sexes, who were older than 18 years old, who had no history of food intolerance or allergy to the ingredients present in the preparation of sweets participated in the sensory analysis. Exclusion criteria were the following factors: individuals under 18 years of age, and having a history of food intolerance or allergy to the ingredients present in the preparation of candy formulations, described in the Informed Consent Form (TCLE). Volunteers who did not sign the Informed Consent form did not participate in the research.

The tests were performed in individual booths, where the sweets were served in disposable cups identified with threedigit codes. Water was then made available for the tasters to rinse their mouths between samples. After applying the test, the data were compiled in excel for analysis of the results.

The acceptability index (AI) of each preparation was calculated according to the following expression: $\mathrm{A}(\%)=\mathrm{A} x$ $100 / \mathrm{B}$, where A is the average score obtained by the product and B is the maximum score given to the product (Teixeira et al., 1987). To find the maximum score given to the product (B), the evaluation scores per volunteer were added, obtained in each sweet parameter, and then the average of these notes was calculated, per volunteer, and finally an analysis of the means obtained was performed, to verify the highest score achieved by each sample. To find the mean score (A) of each sample, the sum of all the means of the evaluation of each candy parameter (the means obtained previously, to find the highest score) was made, and then the value obtained by the number of evaluations was divided, that is, the number of participants in the research (30), in which the average score of each sample was obtained.

The results obtained were calculated with the mean \pm standard deviation of each sweet parameter (color, flavor, aroma and texture) for each sample. They were arranged in tables and chart. 


\subsection{Methodological report for research}

The data presented followed the protocols of teaching, research and scientific methodology, as described by Estrela (2018).

\subsection{Ethical issues}

This study was evaluated and approved by the Ethics Committee on Research with Human Beings (CEP) of the Catholic University Don Bosco-UCDB. CAAE number 43289121.9.00005162.

Each participant received a TCLE, which had an invitation to participate as a subject of the research, where it was clarified that the identity of each participant would be kept confidential and that showed what risks and benefits the present study could bring to the individual. The participant could only participate in the sensory analysis after having carefully read the term and signed it, where he/she showed that he/she was duly informed about the research.

\section{Results}

\subsection{Production of milk sweet formulations}

Four formulations of pasty milk sweet were produced: F1, F2, F3 and F4,as described in item 2.1, these samples were used to perform bromatological and sensory analyses.

\subsection{Bromatological analysis}

Table 1 shows the results found in the bromatological analysis of sweets, which were compared with the values recommended in the technical regulation for the fixation of identity and quality of milk sweets, arranged in Ordinance $\mathrm{N}^{\circ} 354$ (Brasil, 1997).

Table 1. Bromatological analysis of milk sweet formulations, F1 formulations; F2; F3 and F4.

\begin{tabular}{cccccc}
\hline \multirow{2}{*}{$\begin{array}{c}\text { Nutrient } \\
(\%)\end{array}$} & F1 & F2 & F3 & F4 & Legislation* \\
\cline { 2 - 6 } & $36.82 \pm 0.10$ & $13.70 \pm 0.20$ & $27.41 \pm 0.10$ & $09.82 \pm 0.30$ & Max. 30\% \\
\hline Moisture & $1.73 \pm 0.03$ & $1.89 \pm 0.03$ & $2.01 \pm 0.03$ & $1.92 \pm 0.10$ & Max. 2,0\% \\
Ashes & $2.02 \pm 0.61$ & $7.94 \pm 0.10$ & $7.96 \pm 0.40$ & $7.70 \pm 0.10$ & $6 \%$ to $9 \%$ \\
Lipids & $7.59 \pm 0.91$ & $7.37 \pm 0.55$ & $7.37 \pm 0.39$ & $6.87 \pm 0.36$ & Min 5\% \\
Proteins & $79.40 \pm 0.90$ & $12.24 \pm 0.00$ & $78.87 \pm 0.91$ & $12.25 \pm 0.00$ & - \\
\hline
\end{tabular}

Note: F1 (sweet bovine milk with sucrose), F2 (sweet bovine milk with xylitol), F3 (sweet goat milk with sucrose) and F4 (sweet goat's milk with xylitol). Values expressed with the mean \pm standard deviation; (*) Source: Ordinance No. 354 (BRASIL, 1997). Source: Authors.

Regarding humidity, only the F1 sample presented results above the standard limit of 30\%. The F3 sample, although within the recommended limits, with $27.41 \%$, is very discrepant from the values found for the formulations F2 (13.70\%) and F4 $(9.82 \%)$, which are the sweets that contain xylitol in its composition. This discrepancy can be explained by the fact that xylitol works as a reducing agent of water activity, due to the ability of its hydroxyls to bind to water (Cândido \& Campos, 1996), which decreases the amount of free water, and consequently decreases the moisture of the final product. 
Regarding the ash content, all formulations presented values within the established legislation. However, sweets made with goat milk showed higher ash levels compared to bovine milk, this difference can be explained by the higher concentration of total ash in goat's milk (0.85\%) (Park \& Haenlein, 2006), which has a much higher amount than the cow in terms of calcium, phosphorus and potassium (Tables, 2017). According to Demiate and contributors, low ash values may indicate that the products were obtained with other dairy raw materials or with little milk, because the mineral content is usually constant in the raw material (Demiate et al, 2001).

Regarding the results obtained for the lipid content of sweets, the F1 sample presented a result that was too different from the other formulations, being the only one outside the standard limits of the legislation. This difference can be attributed to the high humidity of the F1 sample, where there may have been a possible joint extraction of undesirable, water-soluble substances, as well as the transport of the water itself, the u due to high humidity, the material was more agglutinated, which does not allow the solvent to pass efficiently (Nichelle, 2018). The other formulations did not present significant variations among themselves in the percentage of lipids. However, the lipids present in goat milk have a higher concentration of shortchain fatty acids and fat globules have a smaller diameter ( $65 \%$ with a diameter of less than $3 \mu \mathrm{m})$. Due to these smaller and more dispersed fat globules, they have a larger specific surface, making the action of lipases faster, facilitating digestion (Haenlein, 2004).

The amount of protein in the samples is in accordance with current legislation, with all values above 5\%. Goat milk and bovine milk do not have significant differences in relation to the amount of protein in their compositions, while the former has $3.4 \%$, the second is 3.2\% (Park \& Haenlein, 2006). Similarly, the protein values found for the samples are similar. Although they have similar total values, proteins in goat milk are of high biological value and more digestible (Park, Ramos \& Haenlein, 2007). This is due to the fact that goat milk contains higher levels of $\beta$-casein (53\% vs. $37.5 \%)$ and lower $\alpha$ s 1- casein (15\% vs. $38 \%$ ) than cow's milk (Clark \& Sherbon, 2020). The latter generates a highly hydrated structure, more open and less firm, which facilitates the digestion of the clot in a shorter gastric transit time (Chilliard, Ferlay \& Lamberet, 2003).

The formulations F1 and F3, which were produced with conventional sugar, presented very high values for total carbohydrates when compared to other studies. Oliveira and contributors analyzed sweets from commercial milks and obtained values between 44.77 and 68.98\% for carbohydrates (Oliveira et al, 2010). Another study conducted by Silva found values for carbohydrates ranging from 57.10 to $63.87 \%$. On the other hand, the formulations F2 and F4, where sucrose was replaced by xylitol, there was a considerable reduction in the amount of carbohydrates (Silva, 2016).

Table 2 shows the total caloric values (TVC) obtained in each formulation. The results show that sweets prepared with sucrose present the highest caloric values. As expected, the samples with xylitol showed a significant reduction in the VCT. This is due to the fact that xylitol has only $2.4 \mathrm{Kcal} / \mathrm{g}^{4}$, while sucrose has $4 \mathrm{Kcal} / \mathrm{g}$ (Manhani et al, 2014).

Table 2. Total caloric values (VCT) of F1 milk candy formulations; F2; F3 and F4, equivalent to the 20g (1 tablespoon) section.

\begin{tabular}{ccccc}
\hline \multirow{2}{*}{ Parameter (Kcal) } & \multicolumn{5}{c}{ Sweet milk } \\
\cline { 2 - 5 } & F1 & F2 & F3 & F4 \\
\hline Lipids & 3,63 & 14,29 & 14,33 & 13,86 \\
Proteins & 6,07 & 5,90 & 5,90 & 5,50 \\
Total carbohydrates & 59,52 & 9,79 & 63,10 & 9,80 \\
VCT & 69,23 & 29,98 & 83,32 & 29,16 \\
\hline
\end{tabular}

Note: F1 (sweet bovine milk with sucrose), F2 (sweet bovine milk with xylitol), F3 (sweet goat milk with sucrose) and F4 (sweet goat's milk with xylitol). Values expressed with the mean \pm standard deviation. Source: Authors. 


\subsection{Sensory analysis}

The results of the sensory analysis of the four milk candy formulations produced are shown in Table 3 . They were obtained through the global acceptance test by applying the nine-point hedonic scale, where the following candy parameters were analyzed: color, aroma, flavor and texture.

Table 3. Average of scores obtained for the attributes evaluated using the hedonic scale, and their overall acceptance of each F1 milk candy formulation; F2; F3 and F4.

\section{Sweet milk}

\begin{tabular}{ccccc}
\cline { 2 - 5 } Attributes & F1 & F2 & F3 & F4 \\
\hline Colour & $7.70 \pm 1.53$ & $7.37 \pm 1.73$ & $7.56 \pm 1.75$ & $5.93 \pm 1.72$ \\
Aroma & $7.27 \pm 1.51$ & $7.53 \pm 1.28$ & $7.26 \pm 1.48$ & $6.80 \pm 1.92$ \\
Flavor & $7.40 \pm 1.40$ & $7.60 \pm 1.27$ & $7.26 \pm 1.76$ & $7.17 \pm 1.72$ \\
Texture & $7.13 \pm 1.50$ & $6.93 \pm 2.11$ & $7.23 \pm 1.87$ & $7.10 \pm 1.84$ \\
Global acceptance & $7.37 \pm 1.04$ & $7.36 \pm 1.13$ & $7.33 \pm 1.13$ & $6.75 \pm 1.19$ \\
\hline
\end{tabular}

Note: F1 (sweet bovine milk with sucrose), F2 (sweet bovine milk with xylitol), F3 (sweet goat milk with sucrose) and F4 (sweet goat's milk with xylitol). Values expressed with the mean \pm standard deviation. Source: Authors.

It can be observed that the formulations F1, F2, as well as the formulation F3, obtained a good overall acceptance, with average scores of $7.37 \pm 1.04,7.36 \pm 1.13$ and $7.33 \pm 1,13$, respectively. Similar values were found by Silva et al., who obtained an average overall acceptance score of 7.2 for the standard formulation of goat's milk sweet and 7.4 for the formulation of goat's milk sweet with stevioid sweetener (Silva et al, 2020).

The Formulation F4 was the one that obtained the lowest average overall acceptance score among the formulations, of $6.75 \pm 1,19$. Souza (2018) obtained in his study the elaboration and sensory evaluation of banana and strawberry sweet developed with different sweeteners, a global acceptance note similar to that found in the present study, of 6.1 for the formulations containing xylitol in its composition.

Regarding the color attribute, the F1 formulation was the best evaluated by the tasters, and the average score was $7.70 \pm 1.53$, the highest of this attribute among the four formulations. On the other hand, the F4 formulation obtained the lowest score in the color attribute, which is $5.93 \pm 1.72$, which can be justified by the fact that most tasters prefer the color of the darker milk candy, and the formulation in question was the one that presented a lighter color, when compared to the other samples.

Regarding the aroma attribute, the F2 formulation was the one with the highest average score, with $7.53 \pm 1.28$. In the study by Pieretti and contributors on sweet pasty milk prepared with brown sugar, a score of $7.66 \pm 1.59$ was obtained in the aroma attribute for the formulation of pasty milk sweet with 19\% brown sugar, similar to that found in the present study (Pieretti et al, 2012).

Regarding the flavor attribute, again the formulation F2 obtained the highest average score, with $7.60 \pm 1.27$, a value similar to that found in the study by Silva and contributors who produced creamy milk sweets with goat's whey, cow's milk and umbu pulp. In the study in question, the formulation with $15 \%$ umbu pulp obtained a note in the flavor attribute of 7.4, being, therefore, similar to that found in the present study (Silva et al, 2011).

Finally, regarding texture, the formulation that obtained the highest average grade was F3, with 7.23 1.87 . Again, in the study by Silva and contributors, a similar value of 7.14 was found for the consistency of the formulation with $15 \%$ of umbu pulp (Silva et al, 2011). 
Regarding the Acceptability Index (AI), according to Dutcosky, in order for the product to be considered accepted, in terms of its sensory properties, it is necessary that it obtains an Acceptability Index of at least 70\% (Dutcosky, 2008). Based on the values obtained in the calculation of the AI of each milk sweet formulation, shown in Figure 1, it can be verified that all formulations presented a good acceptability, since the f1 and F2 samples, as well as the F3 sample presented an AI of 81.94\%, $81.75 \%$ and $81.48 \%$, respectively, and the F4 formulation presented an AI of $77.14 \%$.

Figure 1. Acceptability index (AI) of milk candy formulations.

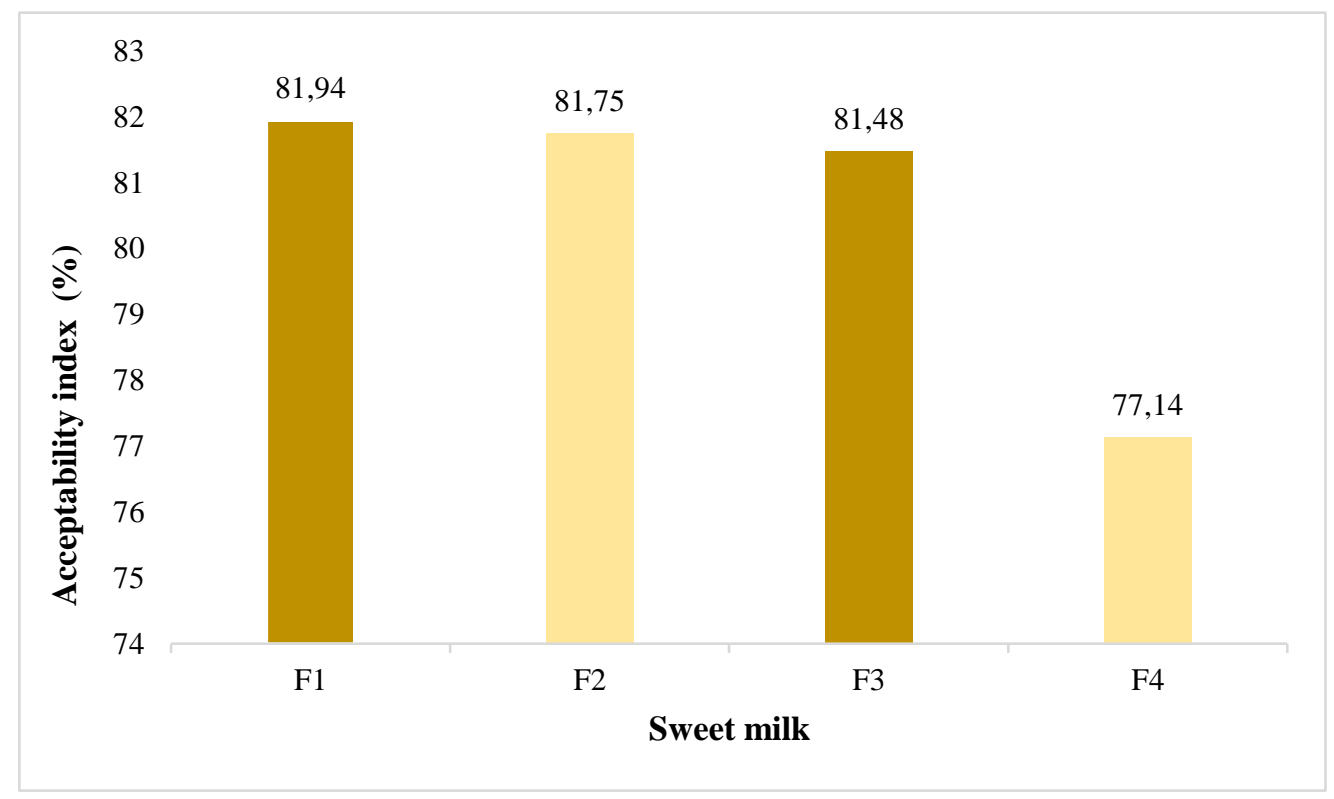

Note: F1 (sweet bovine milk with sucrose), F2 (sweet bovine milk with xylitol), F3 (sweet goat milk with sucrose) and F4 (sweet goat's milk with xylitol). Values expressed with the mean \pm standard deviation. Source: Authors.

Similar data were found in the study by Silva et al. , who obtained an AI of $80 \%$ for the standard formulation of goat's milk sweet, and $82 \%$ for the formulation of goat's milk sweet with stevioid sweetener (Silva et al., 2020). Also, in the study by Foletto and contributors, the AI obtained for the formulation of sweet goat's milk with sucrose was 70\% (Foletto et al., 2006). Therefore, all can be considered well accepted, because they presented an acceptability index greater than $70 \%$.

\section{Conclusion}

The use of xylitol as a substitute for sucrose in sweet milk formulations is feasible. The sweets with this sweetener in its composition were less caloric than the formulations prepared with sucrose, and with a significant reduction in carbohydrate content, so that the formulations with xylitol were well accepted by the tasters, especially the formulation $\mathrm{f} 2$, which presented the second highest AI. Thus, one can think of the dissemination of the use of this sweetener by the food industry, as a potential substitute for sucrose in the production of creamy sweet, due to its proven benefits through research, and the good public acceptance demonstratedin the presentstudy, it is suggested future research in vivo using the formulation to verify the low lipemic activity of the final product. 


\section{References}

Albuquerque, A., Cirino, A. C., Martins, C., \& Gomes, M. (2011). Influência do tipo de açúcar nas propriedades organolépticas do doce de leite. Nutrire. 36(1), 60-60.

AOAC. (2002). Métodos Oficiais de Análise da AOAC International. 17th Edition. Associação de Químicos Analíticos Oficiais (AOAC). Washington.

Brasil (1997). Ministério da Agricultura, Pecuária e Abastecimento. Portaria n. 354, de 04 de setembro de 1997. Aprova o Regulamento Técnico para Fixação de Identidade e Qualidade de Doce de Leite. Diário Oficial da União. 1997. https://www.defesa.agricultura.sp.gov.br/legislacoes/portaria-ma-354-de-04-091997,664.html.

Cândido, L. M. B., \& Campos, A. M. (2016). Alimentos Para Fins Especiais: Dietéticos. Livraria Varella, (4a ed). $1^{\text {a }}$ Edição, São Paulo.

Cenachi, D. B. (2012). Desenvolvimento de leite de cabra fermentado prebiótico com baixo teor de lactose adicionado de B-Ciclodextrina [Dissertação Mestrado, Faculdade de Farmácia, Universidade Federal de Juiz de fora. Minas Gerais].

Clark, S., \& Sherbon, J. W. (2000). Alphas1-casein, milk composition and coagulation properties of goat milk. Small Ruminant Research. 38(1), 123-34.

Demiate, I. M., Konkel, F. E., \& Pedroso, R. A. (2001). Avaliação da Qualidade de Amostras Comerciais de doce de leite Pastoso - Composição Química. Ciência e Tecnologia de Alimentos. 21(1), 108-114.

Dutcosky, S. D. (2008). Análise sensorial de alimentos. Curitiba, PR: Champagnat, 123p.

Estrela, C. (2018). Metodologia Científica: Ciência, Ensino, Pesquisa. Editora Artes Médicas, (3a ed).

Foletto, T. C., Silva, P. V., VilaNova, M. S., Esteves, R. M. G., Osório, M. T. M., \& Fagundes, C. M., (2006). Desenvolvimento e avaliação sensorial de leite de cabra. XV Congresso de iniciação científica - VIII encontro de pós-graduação. Pelotas - RS.

Gaino, N. M. \& Silva, M. (2011). Consumo De Frutose e Impacto Na Saúde Humana. Segurança Alimentar e Nutricional, Campinas, $18(2)$, 88-98.

Chilliard, Y., Ferlay, J. A., \& Lamberet, R. G. (2003).Uma revisão dos fatores nutricionais e fisiológicos que afetam a síntese e a lipólise dos lipídios do leite de cabra. Journal of Dairy Science. 86(5), 1751-1770.

Haenlein, G. F. W. (2004). Goat milk in human nutrition. Small Ruminant Revista Amsterdam. 51(2), 155-63.

Manhani, T., Campos, M., Donati, F. \& Moreno A. (2014). Sacarose, Suas Propriedades e os Novos Edulcorantes. Revista Brasileira Multidisciplinar. 17(12), 2527-2675.

Mussato, S. I. \& Roberto, I.C. (2002). Xilitol: Edulcorante com efeitos benéficos para a saúde humana. Revista Brasileira de Ciências Farmacêuticas. 38(4), 401-413.

Nichelle, P. G. (2018). Bromatologia [recurso eletrônico]. Porto Alegre, SAGAH.

Oliveira, R. M. E., Oliveira, A.R.C., Ribeiro, L.P., Pereira, R., Pinto, S. M., \& Abreu, L.R. (2010). Caracterização química de doces de leite comercializados a granel em Lavras/MG. Revista do Instituto de Laticínios Cândido Tostes. 65 (377), 5-8.

Park, Y. W. M., Ramos, J. M., \& Haenlein, G. F. W. (2007). Physic-chemical characteristics of goat and sheep milk. Small Ruminant Research. 68(1), 88-113.

Park, Y. W., \& Haenlein, G. F. W. (2006). Handbook of milk of non-bovine mammals. Edition Blackwell. UK. (2 th ed., pp. 42-83).

Pieretti, G. G., Seollin, V. J., Bento, R. S., Michika, J. M., Santos, R. D., \& Madrona, G. S. (2012). Doce de leite pastoso elaborado com açúcar mascavo: avaliação sensorial, físico-química e microbiológica. Revista do Instituto de Laticínios Cândido Tostes. 68(390), 59-64.

Silva, A.C. (2016). Desenvolvimento de doce de leite sem adição de sacarose e sem lactose. [Dissertação Mestrado em Ciência e Tecnologia do Leite e Derivados, Universidade Federal de Juiz de Fora, Juiz de Fora].

Silva, D. L., Gonçalves, M. A. F. M., Melo, N. Q. C., Souza, P. V. L., Teresina, M. N., Santos, G. M., \& Barros, N. V. A. (2020). Desenvolvimento e avaliação sensorial de doce de leite caprino. Research, Society and Development. 9(8), e254985713.

Silva, M. S. S., Rossana, M. F. F., Alexandre, J. M. Q., \& Vanessa, M. S. S. (2011). Avaliação físico-química e sensorial de doces cremosos produzidos com soro de leite de cabra, leite de vaca e polpa de umbu. Revista Brasileira de Produtos Agroindustriais. 13, $397-410$.

Souza, K. R., \& Hilbig, J. (2014). Análise sensorial de doce de banana e morango desenvolvido com diferentes edulcorantes. Repositório institucional da Universidade do Sul de Santa Catarina. Tubarão - SC.

Teixeira, E., Meinert, E. M., \& Barbetta., P. A. (1987). Análise sensorial de alimentos. (1a ed). Santa Catarina: UFSC.

Zambom, M. A., ALCALDE, C. R., Martins, E. N., Santos, G. T., Macedo, F. A. F., Horst, J. A., Veiga, D. R. (2005). Curva de Lactação e Qualidade do Leite de Cabras Saanen Recebendo Rações com Diferentes Relações de Volumoso: Concentrado. Brazilian Journal of Animal Science. 34(6), $2515-2521$. 